\title{
Macromolecular prodrugs. XII. Primaquine conjugates: Synthesis and preliminary antimalarial evaluation
}

\author{
ZRINKA RAJIĆ ${ }^{1}$ \\ GABRIJELA KOS ${ }^{1}$ \\ BRANKA ZORC ${ }^{1 *}$ \\ PRATI PAL SINGH ${ }^{2}$ \\ SAVITA SINGH ${ }^{2}$ \\ 1 Faculty of Pharmacy and Biochemistry \\ University of Zagreb, 10000 Zagreb \\ Croatia \\ ${ }^{2}$ National Institute of Pharmaceutical \\ Education and Research, Sector-67 \\ Phase-X, S.A.S. Nagar-160062 \\ India
}

\begin{abstract}
New primaquine conjugates 5-7 with glucosamine and two polymers of polyaspartamide type, poly $[\alpha, \beta-(N-2-h y-$ droxyethyl-DL-aspartamide)] (PHEA) and poly[ $\alpha, \beta-(N-$ -3-hydroxypropyl-DL-aspartamide)] (PHPA), were synthesized, characterized and screened for their antimalarial activity. The conjugates differed in the type of covalent bonding, length of the spacer between the polymeric carrier and drug, molecular mass and drug-loading. Blood-schizontocidal activity of the prepared conjugates was tested against Plasmodium berghei infection in Swiss mice. Polymeric conjugates showed better antimalarial activity than the glucosamine conjugate.
\end{abstract}

Keywords: primaquine, polymer-drug conjugate, polyaspartamide, glucosamine, antimalarial activity

Accepted January 26, 2009

Among all the parasitic diseases that beset human beings in the tropical parts of the world, malaria is still the major cause of morbidity and mortality (1). Primaquine (PQ) is the only currently available drug that is active against both the latent liver forms of relapsing malaria caused by Plasmodium vivax and Plasmodium ovale and the gametocytes from all parasite species causing human malaria, including chloroquine-resistant Plasmodium falciparum. Its usefulness is, however, offset by its inherent toxicity and rapid biotransformation to carboxyprimaquine, which is devoid of significant antimalarial activity (2). Many attempts have been made to synthesize and evaluate analogues of primaquine in the search for compounds that would be more effective or less toxic. Several authors have shown that attachment of an amino acid or peptide residue to the primary amino group protected primaquine against the aforementioned metabolic process and led to a substantial increase in antimalarial activities $(3,4)$. Despite the improved activity/toxicity ratio, most of these derivatives are rapidly hydrolyzed to primaquine by aminopeptidases and endopeptidases (5). Pharmacological activity of primaquine in vivo was significantly improved when this drug was covalently coupled to lysosomotropic drug carriers - polyacryl starch microparticles (6) or asialofetuin (7) via tri-, tetra-, and

\footnotetext{
*Correspondence; e-mail: bzbz@pharma.hr
} 
pentapeptide spacers. Having these observations in mind, we have prepared primaquine conjugates, in which primaquine is covalently bound to a hydrophilic polyamino acid. Two polymers of polyaspartamide type, $\operatorname{poly}[\alpha, \beta-(N-2$-hydroxyethyl-DL-aspartamide $)]$ (PHEA) and poly[ $\alpha, \beta-(N-3-h y d r o x y p r o p y l-D L-a s p a r t a m i d e)](P H P A)$, were chosen as model carriers in polymer-drug conjugates. In this paper, we report the synthesis, characterization and preliminary antimalarial evaluations of the novel primaquine polymeric conjugates, along with a low-molecular-mass glucosamine conjugate. Conjugation of drugs to polymeric carriers to form macromolecular prodrugs might be a useful approach to improve drug solubility, stability and prolong drug release, reduce doses, dosing intervals and drug toxicity or to achieve targetability $(8,9)$. Other delivery systems described in literature include an ethyl cellulose-based transdermal therapeutic system (10), colloidal carriers liposomes, polymeric and lipid nanoparticles (11) and artificial chylomicron emulsion (12).

\section{EXPERIMENTAL}

\section{Chemistry}

Materials and general methods. - Melting points were determined on a Stuart Melting Point Apparatus SMP3 (Barworld Scientific, UK) and were uncorrected. IR spectra were recorded on a FTIR Perkin Elmer Paragon 500 spectrometer (Perkin Elmer, USA). ${ }^{1} \mathrm{H}$ and ${ }^{13} \mathrm{C}$ NMR spectra were recorded on a Varian Gemini 300 spectrometer, operating at 300 and $75.5 \mathrm{MHz}$ for the ${ }^{1} \mathrm{H}$ and ${ }^{13} \mathrm{C}$ nuclei, respectively (Varian, UK). Samples were measured in DMSO- $d_{6}$ solutions at $20^{\circ} \mathrm{C}$ in $5 \mathrm{~mm}$ NMR tubes. Chemical shifts $(\delta)$ in ppm were referred to tetramethylsilane (TMS). UV spectra were recorded on a Shimadzu UV 1601 spectrometer (Shimadzu Co., Japan). Dialysis was performed using cellulose dialysis tubings with a molecular mass cut-off 8,000-15,000 (Serva, Germany). Precoated Merck silica gel $60 \mathrm{~F}_{254}$ plates (Merck, Germany) and solvent systems cyclohexane/ethyl acetate/methanol (3:1:1.5 or 3:1:0.25) were used for thin-layer chromatography. Spots were visualized by short-wave UV light and iodine vapour. Primaquine diphosphate, glucosamine hydrochloride, L-aspartic acid, 2-hydroxyethylamine, 3-hydroxypropylamine and triethylamine (TEA) were purchased from Aldrich (USA). Compounds 1-4 were prepared according to the published procedures (13-15).

Primaquine benzotriazolide $(P Q-B t, 2)$. - Compound 2 was prepared by acylation of primaquine base with chloride 1 (13). Primaquine base was prepared from primaquine diphosphate, keeping the drug solution light protected.

Poly $[\alpha, \beta$-(N-2-hydroxyethyl-DL-aspartamide)] (PHEA, 3). - Polymer 3 was prepared by aminolysis of poly-DL-(2,5-dioxo-1,3-pyrrolidinediyl (PSI) with 2-hydroxyethylamine. PSI was prepared by thermal polycondenzation of L-aspartic acid. Average molecular mass of PHEA was 60,000 (14).

Poly[ $\alpha, \beta$-(N-3-hydroxypropyl-DL-aspartamide)] (PHPA, 4). - Polymer 4 was prepared by aminolysis of poly-DL-(2,5-dioxo-1,3-pyrrolidinediyl (PSI) with 3-hydroxypropylamine (15). 
Primaquine-glucosamine conjugate [1-(4-(6-methoxyquinolin-8-ylamino)pentyl)-3-((tetrahydro-2,4,5-trihydroxy-6-(hydroxymethyl)-2H-pyran-3-yl)methyl)urea] (PQ-G, 5). - A mixture of $0.209 \mathrm{~g}(0.50 \mathrm{mmol})$ primaquine benzotriazolide $2,0.170 \mathrm{~g}(0.75 \mathrm{mmol})$ glucosamine hydrochloride and $0.101 \mathrm{~g}(1.00 \mathrm{mmol})$ TEA in $6 \mathrm{~mL}$ absolute ethanol was stirred at room temperature for 4 days, light protected. Dry ether $(20 \mathrm{~mL})$ was added and the precipitated product 5 was filtered off and triturated with ether several times [yield: $0.203 \mathrm{~g}$ (59 \%); m.p. 122-126 ${ }^{\circ} \mathrm{C}$; IR (KBr): $v_{\max } 3415,3294,3098,3041,2943,2883,1617,1582,1538$, 1456, 1422, 1390, 1094, 1063, 1034, $611 \mathrm{~cm}^{-1} ;{ }^{1} \mathrm{H}$ NMR (DMSO-d $\left.{ }_{6}\right), \delta(\mathrm{ppm}): 8.53-8.51(\mathrm{~d}$, $1 \mathrm{H}, 16), 8.06-8.02(\mathrm{~d}, 1 \mathrm{H}, 14), 7.44-7.40(\mathrm{~m}, 1 \mathrm{H}, 15), 7.17-7.15\left(\mathrm{~d}, 1 \mathrm{H}, 7^{\prime}\right), 6.47$ (s, 1H, 9), 6.42-6.41 (d, 1H, 7), $6.26(\mathrm{~s}, 1 \mathrm{H}, 11), 6.12(\mathrm{t}, 1 \mathrm{H}, 1), 6.10\left(\mathrm{~d}, 1 \mathrm{H}, 2^{\prime}\right), 5.66-5.64\left(\mathrm{~d}, 1 \mathrm{H}, 4^{\prime}\right)$, $5.56-5.58\left(\mathrm{~d}, 1 \mathrm{H}, 5^{\prime}\right), 5.26\left(\mathrm{q}, 1 \mathrm{H}, 6^{\prime}\right), 5.24\left(\mathrm{t}, 1 \mathrm{H}, 3^{\prime}\right), 4.91-4.86\left(\mathrm{t}, 2 \mathrm{H}, 8^{\prime}\right), 4.65(\mathrm{~s}, 1 \mathrm{H}, \mathrm{OH})$, $4.52(\mathrm{~s}, 1 \mathrm{H}, \mathrm{OH}), 4.39$ (s, 1H, OH), 3.82 (s, 3H, 17), 3.69-3.62 (m, 2H, CH-5, OH), 3.00-2.83 $(\mathrm{q}, 2 \mathrm{H}, 2), 1.54-1.41(\mathrm{~m}, 4 \mathrm{H}, 3,4), 1.19(\mathrm{~s}, 3 \mathrm{H}, 6) ;{ }^{13} \mathrm{C}$ NMR (DMSO- $\left.d_{6}\right), \delta$ (ppm): 158.97 (10), 158.19 (1'), 144.61 (8), 144.23 (16), 134.77 (14), 134.48 (13), 129.54 (12), 122.07 (15), $96.08(9), 91.62,91.25\left(7^{\prime}\right), 88.93(11), 71.65,71.21\left(6^{\prime}\right), 70.80,70.23\left(4^{\prime}\right), 69.84,69.82\left(5^{\prime}\right)$, 61.15, 61.05 (8'), 54.96 (17), 54.59, 54.46 (3'), 47.04 (5), 40,76 (2), 33.54 (4), 26.87 (3), 20.22 (6) (atom enumeration is presented in Fig. 1); elemental analysis for $\mathrm{C}_{22} \mathrm{H}_{33} \mathrm{~N}_{4} \mathrm{O}_{7}$ (465.52) (\%): calcd. C 56.76, H 7.15, N 12.04; found: C 56.35, H 7.08, N 12.40].

Poly[ $\alpha, \beta$-(N-2-hydroxyethyl-DL-aspartamide)]-primaquine conjugate (PHEA-PQ) (6). - a) A solution of $0.244 \mathrm{~g}(0.603 \mathrm{mmol})$ primaquine benzotriazolide $(2), 0.191 \mathrm{~g}(1.206 \mathrm{mmol})$ PHEA (3) (calculated as a monomer unit) and $0.122 \mathrm{~g}(1.206 \mathrm{mmol})$ TEA in $12 \mathrm{~mL}$ of dry $N, N^{\prime}$-dimethylformamide (DMF) was stirred at room temperature for 5 days. The solvent was evaporated under reduced pressure and the residue was triturated with acetone and ether until pure product 6 a was obtained [yield: $0.100 \mathrm{~g}(24 \%)$; IR (KBr): $v_{\max }$ $3308,3080,2938,2880,1652,1520,1424,1386,1221,1167,1137,1057,899,880,823,791$, 672, 625, $532 \mathrm{~cm}^{-1}$; UV (ethanol/water 2.5:1): $\lambda_{\max } 266 \mathrm{~nm}\left(A=0.541, \gamma=32 \mu \mathrm{g} \mathrm{mL}^{-1}\right)$; drug loading: $19.5 \%$ ].

b) A solution of $0.300 \mathrm{~g}(0.741 \mathrm{mmol})$ primaquine benzotriazolide (2), $0.190 \mathrm{~g}$ (1.482 mmol) PHEA (3) and $0.299 \mathrm{~g}$ (2.964 mmol) TEA in $10 \mathrm{~mL}$ of dry DMF was heated at 60 ${ }^{\circ} \mathrm{C}$ for $14 \mathrm{~h}$. The solvent was evaporated under reduced pressure and the residue was triturated with acetone and ether until pure product $6 \mathrm{~b}$ was obtained [yield: $0.264 \mathrm{~g}$ ( 47 $\%)$; UV (ethanol/water 2.5:1): $\lambda_{\max } 266 \mathrm{~nm}\left(A=0.673, \gamma=30.2 \mu \mathrm{g} \mathrm{mL}^{-1}\right)$; drug loading: $26 \%]$.

Poly[ $\alpha, \beta$-(N-3-hydroxypropyl-DL-aspartamide)]-primaquine conjugate (PHPA-PQ) (7). A solution of $0.300 \mathrm{~g}(0.741 \mathrm{mmol})$ primaquine benzotriazolide (2), $0.255 \mathrm{~g}$ (1.481 mmol) PHPA (4) (calculated as a monomer unit) and $0.299 \mathrm{~g}(2.961 \mathrm{mmol})$ TEA in $10 \mathrm{~mL}$ of dry DMF was heated at $60{ }^{\circ} \mathrm{C}$ for $4 \mathrm{~h}$. The solvent was evaporated under reduced pressure and the residue was triturated with acetone and ether until pure product 7 was obtained [yield: $0.246 \mathrm{~g}(46 \%)$; IR (KBr) $v_{\max } 3298,3084,2941,2880,1652,1540,1523,1424,1386$, 1261, 1201, 1169, 1134, 1052, 1000, 967, 823, 791, $668 \mathrm{~cm}^{-1}$; UV (ethanol/water 2.5:1): $\lambda_{\max }$ $266 \mathrm{~nm}\left(A=0.712, \gamma=45.2 \mu \mathrm{g} \mathrm{mL}^{-1}\right)$; drug loading: $14.6 \%$ ]. 


\section{Pharmacological evaluation}

Animals. - Swiss mice (15-20 g) of both sexes were obtained from the Central Animal Facility of the National Institute of Pharmaceutical Education and Research, S.A.S. Nagar, India. Mice were randomly distributed into groups and housed in cages (6 per cage) and maintained under standard conditions at $26 \pm 2{ }^{\circ} \mathrm{C}$ and $44-56 \%$ relative humidity, and $10 \mathrm{~h}$ light $14 \mathrm{~h}$ dark cycles each day for one week before and during the experiments. All animals were fed the standard rodent diet (Amrut, India) and were provided clean water containing $0.05 \%$-amino benzoic acid, ad libitum. All studies were performed in accordance with the guidelines for the care and use of laboratory animals, after obtaining the Institutional Animal Ethics Committee Approval.

Antimalarial screening. - The synthesized compounds were tested for their potential blood-schizontocidal activity against a sensitive strain of the rodent malaria parasite Plasmodium berghei KSP11, which is maintained in the laboratory by both cryopreservation and animal passage. Mice, six per group, were infected, intraperitoneally, with a standard inoculum of $1 \times 10^{7}$ infected-erythrocytes (IE; mainly rings) from previously infected (nearly $5 \%$ parasitaemia) donor mice. In each experiment, two hours after initiation of infection, mice in the test groups were administered graded four equal doses of the test compounds homogenously suspended or dissolved in water (vehicle), orally, on day +0 , day +1 , day +2 and day +3 ; a group of negative control (vehicle only) and a group of positive control (chloroquine diphosphate; $8 \mathrm{mg} \mathrm{kg}^{-1}$ per day 4 days) mice were invariably included. For the determination of parasitaemia on day +4 and day +7 , tail-blood thin smears were prepared, stained with Giemsa and examined under the oil-immersion lens of a light microscope. The minimum dose of test compounds that suppressed the infection on both day +4 and day +7 was marked as minimum effective dose (MED), and the MED that could completely eliminate parasitaemia as assessed by the absence of parasites in the smears up to day +60 was designated as minimum curative dose. A compound was considered inactive if at a particular dose it could not suppress the parasitaemia either on day +4 or on day +7 or on both of these days, and the animals died of infection like in the negative control. At $8 \mathrm{mg} \mathrm{kg}^{-1}$ per day chloroquine for 4 days, all the positive control mice were slide negative on both day +4 and day +7 .

Statistical significance was determined using the SigmaStat 2.03 software (Student-Newman-Kelus method).

\section{RESULTS AND DISCUSSION}

\section{Chemistry}

Novel primaquine conjugates with glucosamine and two polyaspartamides, PHEA and PHPA, were prepared. Conjugation with glucosamine was performed in order to obtain a low-molecular-mass water soluble conjugate. Glucosamine primaquine conjugate (PQ-G, 5) was synthesized by aminolysis of primaquine benzotriazolide 2 with glucosamine, following our previously published method for primaquine ureas (13). Compound 2 was prepared by acylation of primaquine base with 1-benzotriazole carboxylic acid chloride $(\mathrm{BtcCl}, \mathbf{1})$ (Scheme 1). Conjugate $\mathbf{5}$ is fairly soluble in water and well solu- 
<smiles>COc1cc(NC(C)CCCNC(=O)NC2(CO)OC(C)C(O)C2O)c2ncccc2c1</smiles>

Fig. 1. Atom enumeration of primaquine-glucosamine conjugate (5).

ble in the ethanol/water (2.5:1) mixture. IR spectrum shows absorptions at $3415(\mathrm{OH})$, $3294(\mathrm{NH})$ and three typical urea carbonyl absorptions at 1617, 1582 and $1538 \mathrm{~cm}^{-1}$. ${ }^{1} \mathrm{H}$ NMR spectrum of the primaquine conjugate reveals pyridine hydrogens at 8.53 and 7.40 ppm, benzene hydrogens between 6.47 and 6.26 ppm, three NH groups (at 6.42, 6.12 and $6.10 \mathrm{ppm}$ ), glucosamine hydrogens between 5.66 and $4.39 \mathrm{ppm}$, hydroxyl at anomeric C-atom at 7.17-7.15 ppm and methoxy group at $3.82 \mathrm{ppm}$. A new urea carbonyl at 158.19 and absorptions between 91 and $54 \mathrm{ppm}$ of the glucosamine moiety are present in the ${ }^{13} \mathrm{C}$ NMR spectrum, in addition to $\mathrm{C}$-atoms of primaquine residue. Fig. 1 represents the chemical structure of compound 5 and atom enumeration.

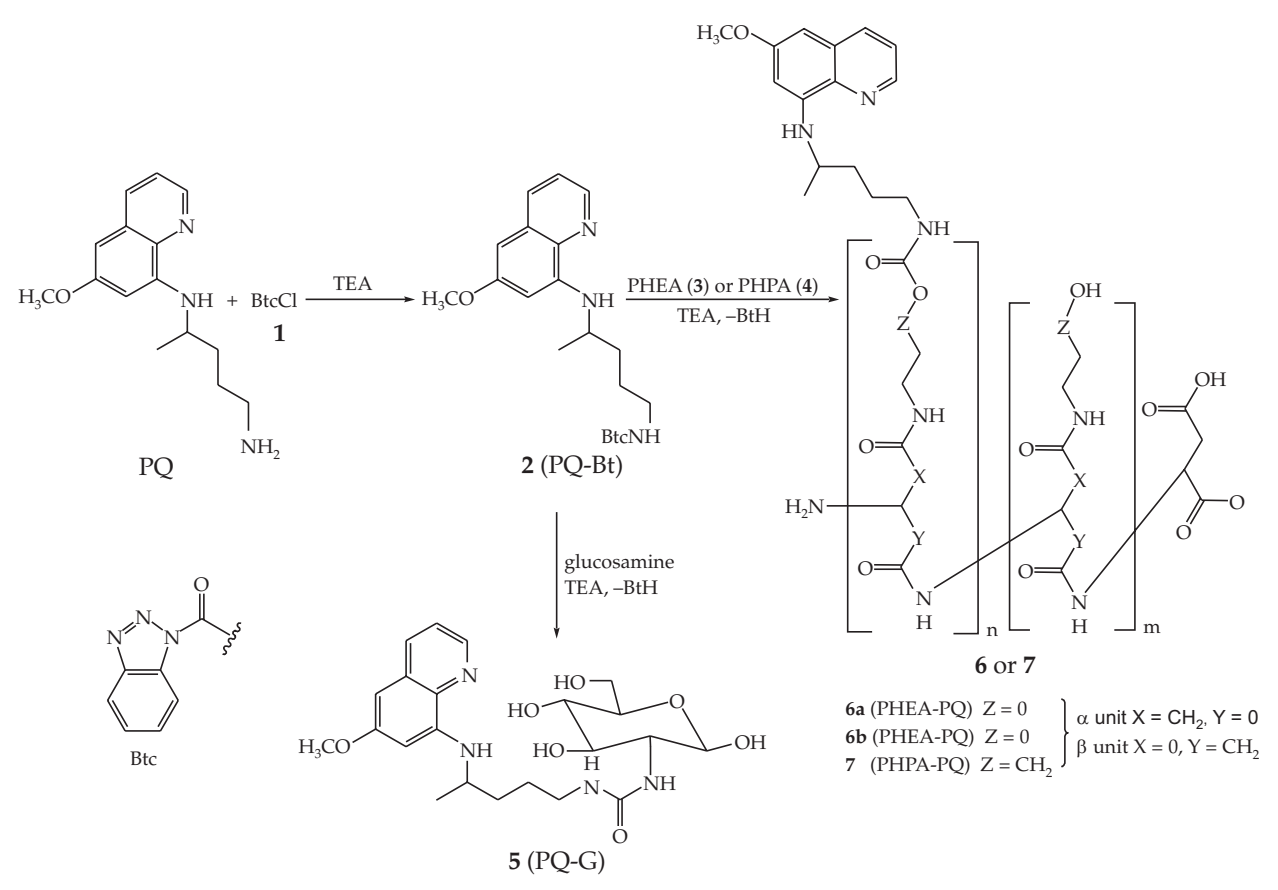

Scheme 1 
Benzotriazolide 2 was a convenient starting compound for the preparation of polymer-drug conjugates as well (Scheme 1). Two polymers of polyaspartamide type, PHEA (3) and PHPA (4), were chosen as model carriers in polymer-drug conjugates because of their physiological acceptance and excellent physicochemical characteristics such as high aqueous solubility, low toxicity (16), abundant hydroxyl groups for drug conjugation and availability in a wide range of molecular masses. The starting polymers PHEA and PHPA were prepared by aminolysis of poly-DL-(2,5-dioxo-1,3-pyrrolidinediyl) (PSI) with 2-hydroxyethylamine and 3-hydroxypropylamine, respectively, while PSI was prepared by thermal polycondensation of L-aspartic acid $(14,15)$. The reaction between 2 and PHEA/ PHPA was performed in a DMF solution, in a molar ratio 1:2 (calculated as monomer units). The following polymer-drug conjugates were prepared: PHEA-PQ (6a), PHEA-PQ (6b) and PHPA-PQ (7). In these conjugates, primaquine is bound to hydroxyl bearing polymeric carriers by cleavable carbamate bonds. The synthesized conjugates differed in their spacer length and drug loading.

Drug-loading in polymer-drug conjugates was estimated by UV-spectroscopy at $\lambda=$ $266 \mathrm{~nm}$ using the calibration line for primaquine $(A=80.725 ; \gamma+0.0372, R=0.9997)$. Percentage of primaquine ranged from 14.6 to $26 \%$. Drug-loading in the conjugates was not strictly stoichiometric. The experimentally determined drug-loading was lower than the expected loading due to incomplete coupling reactions (the molar ratio of reactant 2 and monomer units of PHEA or PHPA 1:1 enabled binding of the drug to half of the hydroxyl groups available). Drug loading was higher if the reaction was performed at higher temperature. No substituted hydroxyl groups assured hydrosolubility of the conjugates.

The proof that primaquine was covalently bound in the prepared polymer-drug conjugates was found in the UV-spectra. The conjugates absorbed UV-light in the same absorption ranges as primaquine, whereas PHEA and PHPA had no UV-absorption at these wavelengths. The absence of nonconjugated drug was confirmed by TLC using solvent systems in which polymer derivatives remained at the start and primaquine and benzotriazolide 2 moved with the mobile phase. In the IR spectra of conjugates $\mathbf{6 a}, \mathbf{b}$ and 7, strong amide carbonyl absorptions at 1652 (amide I) and $1540 \mathrm{~cm}^{-1}$ (amide II) are present, similarly to PHEA and PHPA. Carbamate absorption overlaps with these absorptions, while new absorptions coming from aromatic primaquine moieties are visible at 3080,823 and $792 \mathrm{~cm}^{-1}$.

\section{Biological results}

One primaquine glucosamine conjugate (5) and three polymeric conjugates $(6 \mathbf{a}, \mathbf{b}$ and 7) were tested for their blood-schizontocidal activity against the rodent malaria parasite Plasmodium berghei infection in mice (Table I). The compounds were administered from day 0-3 post-infection, orally. Except for compound $\mathbf{6 a}$, which was tested at $75 \mathrm{mg} \mathrm{kg-1}$ per day for 4 days, all the remaining compounds were tested at $150 \mathrm{mg} \mathrm{kg}^{-1}$ per day for 4 days. For the assessment of the potential blood-schizontocidal activity of the test compounds, parasitaemia in treated mice on day +4 and day +7 was compared with those of the negative-control and positive-control mice on the same days. Mice in the negative-control group were administered vehicle only, and all of these mice became patent on day +2 , showed $5.6 \pm 1.0 \%$ and $16.8 \pm 4.3 \%$ parasitaemia on day +4 and day +7 , respectively, and finally died of up to $75 \%$ infection between day +10 and day +14 post 
Z. Rajić et al.: Macromolecular prodrugs. XII. Primaquine conjugates: Synthesis and preliminary antimalarial evaluation, Acta Pharm. 59 (2009) 107-115.

Table I. Antimalarial evaluation of primaquine conjugates in vivo (parasite: Plasmodium berghei, host animals: Swiss mice ${ }^{a}$ )

\begin{tabular}{|c|c|c|c|c|}
\hline \multirow{2}{*}{ Conjugate } & \multirow{2}{*}{ Dose $\left(\mathrm{mg} \mathrm{kg}^{-1}\right)^{\mathrm{b}}$} & \multicolumn{3}{|c|}{ Parasitaemia (mean \pm SD) on day $(\%)$} \\
\hline & & day +4 & day +7 & day +28 \\
\hline PQ-G (5) & 150 & $0.2 \pm 0.2$ & $2.6 \pm 1.0$ & all died \\
\hline PHEA-PQ (6a) & 75 & $0.0_{2} \pm 0.0_{4}$ & $2.7 \pm 1.1$ & all died \\
\hline PHEA-PQ (6b) & 150 & $0.1 \pm 0.2$ & $1.3 \pm 0.6$ & $\begin{array}{l}2 \text { died; } 4 \text { survived with } \\
40-50 \% \text { parastitaemia }\end{array}$ \\
\hline PHPA-PQ (7) & 150 & $0.2 \pm 0.2$ & $6.6 \pm 1.8$ & $\begin{array}{c}\text { all survived with } \\
44 \pm 6.54 \% \text { parasitaemia }\end{array}$ \\
\hline $\begin{array}{l}\text { Chloroquine } \\
\text { control }\end{array}$ & 8 & 0 & 0 & $\begin{array}{l}1 \text { died; } 5 \text { survived } \\
\text { without infection }\end{array}$ \\
\hline Vehicle control & $0.5 \mathrm{~mL}$ per mouse & $6.4 \pm 1.7$ & $19.6 \pm 2.5$ & all died ${ }^{\mathrm{c}}$ \\
\hline
\end{tabular}

a $n=6$

b Drugging schedule: from day +0 to day +3 .

c Average survival of untreated animals (vehicle control): 14 days.

infection. Positive-control group mice were administered chloroquine $\left(8 \mathrm{mg} \mathrm{kg}^{-1}\right.$ per day, 4 days); these mice did not show any patent parasitaemia on either day +4 or day +7 .

Compared to the negative controls, mice treated with compound $\mathbf{5}$ showed significantly $(p<0.001)$ lower parasitaemia; however, all these mice died of infection before day +28 , similarly to negative controls. Of the six mice treated with compound $6 \mathbf{a}$, on day +4 , only one showed patent parasitaemia, while the remaining five mice remained slide negative. On day +7 , all the compound 6a-treated mice became patent but with significantly $(p<0.001)$ suppressed infection compared to negative controls; later on, all the mice died of infection. Though compound $\mathbf{6 b}$ showed almost similar activity, four of the treated mice survived until day +28 albeit with up to $45 \%$ parasitaemia; later on, these mice also died of infection. On the other hand, all the mice treated with compound 7 survived beyond day +28 , again with up to $45 \%$ parasitaemia and later died of infection. It is important to note here that all the mice treated with polymeric conjugates, compared to negative-controls and the glucosamine conjugate, on day +4 , were either aparasitemic or had significantly $(p<0.001)$ lower parasitaemia. Among polymeric conjugates, compound $\mathbf{6 b}$ appeared to be the best with respect to suppression of parasitaemia. Nevertheless, all the mice treated with compound 7 survived beyond day +28 , which may be explained on the basis of the infection-induced immunity that these mice would have acquired due to the continued presence of infection for a relatively long period.

\section{CONCLUSIONS}

The prepared polymer-primaquine conjugates could be potentially useful antimalarial primaquine prodrugs of increased solubility and prolonged activity. Preliminary experiments showed a significant blood-schizontocidal activity of PHEA-PQ and PHPA-PQ conjugates against parasitaemia induced in experimental animals. The polymeric conjugates showed better antimalarial activity than the glucosamine conjugate. 
Acknowledgements. - Support to this study was provided by the Ministry of Science, Education and Sports of the Republic of Croatia (Project No. 006-0000000-3216).

Acronyms and codes. - Bt - 1-benzotriazolyl; Btc - 1-benzotriazolylcarbonyl; DMF $N, N^{\prime}$-dimethylformamide; IE - infected erythrocytes; MED - minimum effective dose; NMR - nuclear magnetic resonance; PHEA - poly $[\alpha, \beta-(N-2-h y d r o x y e t h y l-D L-a s p a r t a m i-$

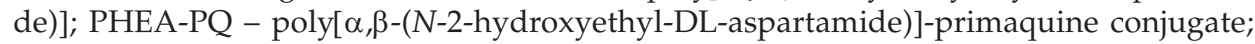
PHPA - poly $[\alpha, \beta-(N-3$-hydroxypropyl-DL-aspartamide)]; PHPA-PQ - poly[ $\alpha, \beta-(N-3-h y-$ droxypropyl-DL-aspartamide)]-primaquine conjugate; $\mathrm{PQ}$ - primaquine; $\mathrm{PQ}-\mathrm{Bt}$ - primaquine benzotriazolide; PQ-G - primaquine-glucosamine conjugate; PSI - poly-DL-(2,5-dioxo-1,3-pyrrolidinediyl); TEA - triethylamine.

\section{REFERENCES}

1. S. Vangapandu, S. Sachdeva, M. Jain, S. Singh, P. P. Singh, C. L. Kaul and R. Jain, 8-Quinolinamines and their pro prodrug conjugates as potent blood-schizontocidal antimalarial agents, Bioorg. Med. Chem. 11 (2003) 4557-4568; DOI: 10.1016/j.bmc.2003.07.003.

2. N. Vale, R. Moreira and P. Gomes, Primaquine revisited six decades after its discovery, Eur. J. Med. Chem. (2008) (in press); DOI: 10.1016/j.ejmech.2008.08.011.

3. R. Jain, S. Jain, R. C. Gupta, N. Anand, G. P. Dutta and S. K. Puri, Synthesis of amino acid derivatives of $8-[$ (4-amino-1-methylbutyl)amino]-6-methoxy-4-substituted/4,5-disubstituted-quinolines as potential antimalarial agents, Ind. J. Chem. 33B (1994) 251-254.

4. M. Jain, S. Vangapandu, S. Sachdeva and R. Jain, Synthesis and blood-schizontocidal antimalarial activities of 2-substituted/2,5-disubstituted-8-quinolinamines and some of their amino acid conjugates, Bioorg. Med. Chem. 12 (2004) 1003-1010; DOI 10.1016/j.bmc.2003.12.029.

5. R. Borissova, P. Stjärnkvist, M. O. Karlsson and I. Sjöholm, Biodegradable microspheres. 17. Lysosomal degradation of primaquine-peptide spacer arms, J. Pharm. Sci. 84 (1995) 256-262.

6. P. Stjärnkvist, Biodegradable microspheres: XIV. Effect of microparticle-bound primaquine on $L$. donovani in mice, Int. J. Pharm. 96 (1993) 23-32; DOI: 10.1016/0378-5173(93)90208-W.

7. A. Trouet, P. Pirson, R. Baurain and M. Masquelier, Cell Targeting of Primaquine, in Handbook of Experimental Pharmacology, Vol. 68, Part 2, Springer-Verlag, Berlin 1984, pp. 253-264.

8. R. Duncan, Polymer-drug Conjugates: Targeting Cancer, in Biomedical Aspects of Drug Targeting (Eds. V. Muzykantov and V. Torchilin), Kluwer Academic Publishers, Norwell 2002, pp. 193-209.

9. R. Duncan, The dawning era of polymer therapeutics, Drug Discovery 2 (2003) 347-360; DOI: $10.1038 / \mathrm{nrd} 1088$.

10. P. Mayorga, E. Deharo, F. Puisieux and G. Couarraze, Interpretation and prediction of plasma levels of primaquine following transdermal delivery in Swiss mice, Int. J. Pharm. 155 (1997) 99-107.

11. A. A. Date, M. D. Joshi and V. B. Patravale, Parasitic diseases: Liposomes and polymeric nanoparticles versus lipid nanoparticles, Adv. Drug Deliv. Rev. 59 (2007) 505-521; DOI: 10.1016/j.addr. 2007.04.009.

12. A. M. Dierling and Z. Cui, Targeting primaquine into liver using chylomicron emulsions for potential vivax malaria therapy, Int. J. Pharm. 303 (2005) 143-152; DOI: 10.1016/j.ijpharm.2005.07. 015.

13. G. Džimbeg, B. Zorc, M. Kralj, K. Ester, K. Pavelić, J. Balzarini, E. De Clercq and M. Mintas, The novel primaquine derivatives of $\mathrm{N}$-alkyl, cycloalkyl or aryl urea: synthesis, cytostatic and antiviral activity evaluations, Eur. J. Med. Chem. 43 (2008) 1180-1187; DOI: 10.1016/j.ejmech.2007. 09.001. 
14. J. Vlasák, F. Rypáček, J. Drobník and V. Saudek, Properties and reactivity of polysuccinimide, J. Polym. Sci. Polym. Symp. 66 (1979) 59-64.

15. M. Lovrek, B. Zorc, B. Boneschans and I. Butula, Macromolecular prodrugs. VIII. Polymer-gemfibrozil conjugates, Int. J. Pharm. 200 (2000) 59-66; DOI: 10.1016/S0378-5173(00)00340-9.

16. G. Antoni, C. Arezzini, F. Cocola, G. Gazzei and P. Neri, Pharmacological and toxicological evaluation of polyhydroxyethylaspartamide (PHEA) as a plasma substitute, Farmaco Ed. Pr. 34 (1979) 146-156.

\section{Makromolekulski prolijekovi. XII. Konjugati primakina: Sinteza i preliminarno ispitivanje antimalarijskog djelovanja}

ZRINKA RAJIĆ, GABRIJELA KOS, BRANKA ZORC, PRATI PAL SINGH i SAVITA SINGH

U radu je opisana sinteza, karakterizacija i ispitivanje antimalarijskog djelovanja novih konjugata primakina 5-7 s glukozaminom i dva polimera poliaspartamidnog tipa, poli $[\alpha, \beta-(N-2-h i d r o k s i e t i l-D L-a s p a r t a m i d o m)]$ (PHEA) i poli[ $\alpha, \beta-(N-3$-hidroksipropil-DL-aspartamidom)] (PHPA). Konjugati su se razlikovali po vrsti kovalentne veze, duljini razmaknice između polimernog nosača i ljekovite tvari, molekulskoj masi i količini vezanog lijeka. Šizontocidno djelovanje pripravljenih konjugata ispitano je na miševima inficiranima parazitom Plasmodium berghei. Polimerni konjugati pokazali su jače antimalarijsko djelovanje nego konjugat s glukozaminom.

Ključne riječi: primakin, polimer-lijek konjugat, poliaspartamid, glukozamin, antimalarijsko djelovanje Faculty of Pharmacy and Biochemistry, University of Zagreb, 10000 Zagreb, Croatia

National Institute of Pharmaceutical Education and Research, Sector-67, Phase-X, S.A.S.

Nagar-160062, India 